\title{
İlköğretim İkinci Kademe Öğrencilerinin Olasılık Bilgisini Oluşturma ve Pekiştirme Süreci
}

\author{
Arş. Gör. Yasemin KATRANCI* \\ Kocaeli Üniversitesi, Eğitim Fakültesi, İlköğretim Bölümü, Matematik Eğitimi Anabilim Dalı, \\ Kocaeli / Türkiye

\section{Prof. Dr. Murat ALTUN} \\ Uludağ Üniversitesi, Eğitim Fakültesi, İlköğretim Bölümü, Matematik Eğitimi Anabilim Dalı \\ Bursa / Türkiye
}

\section{Özet}

İlköğretim öğrencilerinin, öğrenmekte zorlandıkları kavramların başında, olasılık ile ilgili olanlar gelmektedir. Bu yönüyle olasılık öğretimi, araştırma ihtiyacı duyulan bir alan olagelmiştir. Bu çalı̧̧mada, uygun bir öğrenme ortamında, ilköğretim ikinci kademe öğrencilerinin, Olasılık Öğrenme Alanı ile ilgili; deneysel olasılık, teorik olasılık, bağımlı ve bağımsız olaylar kavramlarını, oluşturma ve pekiştirme süreçleri incelenmiştir. Çalışma, başarı düzeyi yüksek iki öğrenci ile grup çalışması şeklinde gerçekleştirilmiştir. Öğretimde öğrencilerin ön bilgilerini ve deneyimlerini kullanabilmelerine imkân veren, sıralı dört etkinlik/problem tasarlanmış ve kullanılmıştır. Çalışma, bir örnek olay incelemesidir. Öğretimde bilişsel süreçlerin incelenmesi ve soyutlamanın açıklanması "TKO+P" (Tanıma, Kullanma, Oluşturma+Pekiştirme) modeli esas alınarak gerçekleştirilmiştir. Çalışmada öğrencilerin 
daha önce oluşturdukları bilgiyi, sonrakilerde kullandıkları, olasılıkla ilgili hedeflenen bilgiyi belirli düzeyde doğru olarak oluşturdukları ve pekiştirdikleri gözlenmiştir. Ayrıca çalışma, gerçek etkinliklerin ve etkinlik tabanlı öğretimin, bilginin yapıland1rılmasına olan katkısını ortaya koymuştur.

Anahtar Kelimeler: Soyutlama; Yapılandırma; Pekiştirme; Olasılık bilgisi.

\title{
Constructing and Consolidating Process of the Second Level Students of Primary Schools for their Knowledge of Probability
}

\begin{abstract}
Subjects with regards to probability are leading concepts that primary school students have difficulty to learn. In this regard, teaching the probability subjects become a field that needed to be searched. In this study, constructing and consolidating process of the Primary School Second Level for the concepts related to learning field of probability such as experimental probability, theoretical probability, concepts of dependent and independent events in an appropriate teaching environment have been analyzed. The group study has been carried out together with two students who had high level achievement scores. In the teaching period, four sequential activities / problems that allow students to use their prior knowledge and experiences have been designed and used. The study was a case study analyze. Analyzing cognitive processes and explaining abstraction in teaching was realized by using "TKO+P" model (Recognizing, Building-with, Constructing+Consolidation) as a basis. In the study, it has been observed that students using their prior knowledge for the later ones could, construct and consolidate the targated knowledge in regard to the subject probability appropriately in a certain level. Besides, this study set forth the contribution of authentic activities and activity based teaching to the construction of the knowledge.
\end{abstract}

Keywords: Abstraction; Construction; Consolidation; Probability knowledge. 


\section{Extended Summary}

\section{Purpose}

Constructivist learning theory is related with construction of knowledge and is among the theories that have an effect on teaching mathematics. According to this theory, knowledge is not frozen facts but it is a process which is constructed by individuals' experiences and activities. Knowledge has never been independent from individuals, it changes from case to case and it has been interpreted personally (Yurdakul, 2004). Knowledge is constructed by individuals. Learning is not objective but it is subjective. Everyone learns peculiar to himself or herself. It can be defined as a process of construction of meaning by an individual from his/her own experiences. The idea that individuals construct knowledge personally and create meanings from their own experiences directed researchers to analyze the process of construction of knowledge and the factors that affected this process.

Mathematics is a science of abstraction and this aspect of mathematics directed researchers to use abstraction as synonymous to construct knowledge. Because, mathematics is a science of abstraction and mathematical concepts are acquired by abstraction (Altun, 2008). This study is related with abstracting the concepts of experimental and theoretical probability, as well as the concepts of dependent and independent activities in the field of probability subject. In this study, the process of constructing and consolidation of determined concepts has been analyzed in a learning environment that has been prepared in the constructivist theory framework. The study is required to be carried out 
with (i) a teaching by problem solving / activity based and should let students to use their informal knowledge and (ii) through problems / activities selected from real life.

The probability subject which is chosen for this study is a branch of mathematics dealing with the frequency of an event. The essential objective for teaching probability subject is to be able to make a strong prediction about the probability of an event to occur (Altun, 2008) and this is one of the leading subjects that both teachers and students have difficulties to work with. Although probability has an important role in our decisions we took in many occupations and in our daily life, it is not easy to understand the concept of probability for most of the students (Memnun-Sezgin, 2008). The primary objective of this study is to prepare an environment where students can study meaningful mathematics, apply the teaching designed for this environment and make a model study which can also be suitable for the other subjects of mathematics.

This study is based on abstraction concept since mathematics is a science of abstraction and mathematical knowledge is constructed as a result of abstraction. Abstraction as one of the basic concepts that the study is based on is defined as "discriminating certain features from a concept" by Sierpinska (1994). In the simplest form, abstraction is known as "the process of transition from concrete to abstract".

Since the process of abstraction cannot be observed directly (Dreyfus, 2007), it is needed to determine observable actions which can 
inform us about abstraction process. RBC model which was produced by Herskowitz, Schwarz, and Dreyfus (2001) is chosen as theoretical basis for this study. The model is named by using the initial letters of the words which are Recognizing, Building with and Constructing. Since each of these actions can be observable, it can be possible to analyze the abstraction process deeply.

RBC model has appointed some socio cultural and epistemological principles as a basis for itself. These principles are based on Davydov's (1990) philosophy of constructing knowledge and Leont'ev's (1981) theory of activity (Katranc1, 2010). In this study, observing actions like recognizing, building with and constructing depends on this theory of activity. These actions have been observed with the help of activities that are prepared.

Recognizing; refers to known structures (Bikner-Ahsbahs, 2004). It is using a structure that has been constructed previously (Schwarz, Dreyfus, Hadas and Hershkowitz, 2004). Building with, combine known information components with the new content in the process. It also compromises the recognizing period. It is using the previous mathematical structures in order to achieve a given objective (Schwarz et al., 2004). Building with can be realized by giving a clue or reminding a source to students (Hershkowitz, Schwarz and Dreyfus, 2001). Constructing is a process which is recognized as re-organizing and re-constructing processes and known as constructing new information. "It is a process of creating a new meaning as a result of combining existing mathematical knowledge components and having a 
re-organization between this knowledge" (Bikner-Ahsbahs, 2004). Combining and consolidation have an undeniable importance on creating abstraction. $\mathrm{RBC}+\mathrm{C}$ model which sees abstraction as a whole comes into existence. In addition to other three actions consolidation action is integrated. Consolidation is using the structures of previous activities for a new activity and constructing a new structure by combining these structures (Katranc1, 2010).

In this study, experimental and theoretical probability, dependent and independent actions, abstraction and consolidation processes of concepts have been analyzed. It has been thought that this study can contribute to the literature in terms of abstracting more specific concepts related with the subject of probability and explaining the consolidation action which is integrated to RBC model later.

\section{Method}

This study is a "case study". While case studies can be both qualitative and quantitative, in both cases the purpose is to give the results related with a specific condition. This study is a qualitative case study. In analyzing the process of constructing the students' knowledge, the models of $\mathrm{RBC}$ and $\mathrm{RBC}+\mathrm{C}$ has been taken as a reference. Recognizing, building with, construction and consolidation actions which are known as epistemological have been analyzed by using interviews, observations and document analysis. For activities / problems related with the daily life of the students, they have been used and during the application, process of these activities /problems, recognizing the previous knowledge, building with this knowledge, thinking styles while 
constructing new structures and consolidation of the acquired knowledge have been analyzed.

\section{Study Group}

In the selection of the students who participated in the study, first a pre-test has been carried out to check the previous knowledge of the students in order to test whether they can learn the subject of probability. First of all, this test prepared to check the previous knowledge has been discussed with mathematics teachers of the school and they approved the test. According to the results of the pre-test, it has been seen that 65 students out of 102 students in the $7^{\text {th }}$ grade and constitute the universe of the research can learn the subject of probability. SBS placement test results as well as their average scores for the subject of mathematics of these 65 students have taken from the school administration. By taking the average of these two scores, a score chart has been prepared and two students with high level mathematics achievement have been selected from this chart. These two students constituted the study group of the research.

\section{Data Collection Instruments and Collection of the Data}

Worksheets that have been used during the study, video records and observations from the study environment are the data collection instruments of the research. There are four worksheets and each worksheet is related with concepts like experimental and theoretical probability, dependent and independent actions from primary school $8^{\text {th }}$ grade is subject of probability. 
In the selection of activities and organizing their types, in order to get the results expected from the clinical interviews, features like (I) convenient to discussions, (ii) open ended and (iii) providing opportunities to reveal the thinking levels of the students has been searched (Tanışl1, 2008). Among these activities, "Activity 1: Which ball has to be chosen?" and Activity 2: Where is my pencil?" has been prepared according to RBC model and "Activity 3: Win or Lose!" and Activity 4: The Chance of Drawn" has been prepared according to $\mathrm{RBC}+\mathrm{C}$ model to show how students construct their knowledge.

\section{Analysis of Data}

In order to analyze and interpret the data, descriptive analysis among qualitative analysis types has been used. In this study carried out in the light of $\mathrm{RBC}$ and $\mathrm{RBC}+\mathrm{C}$ models, the worksheets of students and video recordings have been made as written texts according to recognizing, building with, construction and consolidation actions. In order to make findings meaningful, explain the among between findings and get some results from the findings, the data has been interpreted based on data obtained in the study.

\section{Results}

In this study carried out together with Burcu and Berkay, the students' knowledge construction processes about the subject of probability, experimental and theoretical probability, dependent and independent action concepts have been presented in the light of recognizing, building with, construction and consolidation actions. The names of the students and the researcher have been used in the research, as 
follows: BU: Burcu, B: Berkay and R: Researcher

\section{The Analysis of the Process and Comments}

4B: Because now if you can see inside the bag, it won't be a random selection that is it will be a specific selection. As we can see inside the bag, we can know which ball we will choose.

The above answer is given by the students to the question why inside of the bg forwarded to them in the activity paper nr:1. From the phrases like "random selection", "specific selection", it has been understood that the student recognizes the concepts and uses them. The activity has been continued and students completed the desired applications and realized the dialogues stated here below.

31R: Now, What does this want to say to you? What does this table explain to us?

32B: It is probability, isn't it?

33R: Probability is O.K. but we drew 25 times?

34BU: There were more white balls and we drew more white balls

35B: There were less green balls, why aaa yes, it was happened so!

It has been seen that both students recognize and use the concept of probability. The student was surprised in $35 \mathrm{~B}$, it is because he thinks that the possibility of drawing the color which is less in the bag should be minimal. In this case it has been seen that student recognizes the knowledge structure and builds with it in the activity. The dialogues of students related with the concept of construction like experimental probability and theoretical probability are as follows:

118R: Do you use experiments only in Science lessons? 119B: No, we use them also in mathematics 
120R: Can you say that thing that you did a while ago is also a mathematical experiment?

121BU: Yes

122R: What can we call these drawing actions?

123BU: Experiment

124R: We can call as an experiment. Then how can we call this probability?

125B: Probability of experiment.

131BU: In the second.... (She thinks). It can be a scientific probability.

As it has been seen that they constructed the concept of experimental probability, they produced the concept of scientific probability for the concept of theoretical probability.

The study has been continued and the second activity has been started. The requirements in the activity instructions have been implemented by students.

322B: 15 divided by 5

323BU: 3 divided by 1. Pink pencil and green pencil. There are 4 pink and 6 green pencils.

324B: 15 divided by 4, 15 divided by 6 .

325R: Well, what did you say about your probability that you did according to your drawings?

326BU: Experimental probability

328B: I called probability

330BU: I called scientific probability

331B: I do not want to change probability

In 323BU it has been seen that the student said directly the result by making simplification. She had also expressed similarly in the first activity. It also shows that is student has constructed the knowledge structure previously and also has used it in this activity. They contio- 
nued using the concept of "experiment probability" in this activity as they used in the first activity instead of experimental study. Therefore, it can be said that they constructed the structure of of and 7 means tat knowledge they can abstract.

617R: What if these events are affecting each one another, that is if first event is effecting the second one, what kind of events are they for you?

618BU: Dependent

622BU: You can not put back the stone that you drew on its old place, so it affects the probability of the stones that are drawn after it.

642BU: The stones are not affecting each another

643R: How can you explain this? How did you understand that it did not affect?

644BU: The chances are still the same for two

645R: Is there any relationship between the first and second draw?

Can we talk about an effect?

646BU: No

647R: If it is not so, then, what kind of events are they?

648B: Independent events

It has been clearly seen in 618BU and 648BU that students have consolidated the concepts of dependent and independent actions.

They have recognized whether actions were dependent or independent and they called these events as dependent and independent. It has been seen that students have consolidated these concepts.

770R: Can you explain this relationship?

771B: Dependent probability. Interconnected events

772A: In what ways are they connected?

773BU: The previous event is affecting the later one.

801R: It is not affecting. Then what kind of events are they?

802BU, B: Independent. 


\section{Discussion and Conclusion}

The Appropriateness of Learning Environment to the Knowledge Construction Process

Activity implementing/problem solving based teaching have been applied during the entire study and the students have showed interest to all activities in the study. From this point of view, it can be said that the study is suitable to Leont'ev's (1981) activity theory which takes into consideration the factor of environment. It can be said that the activities prepared are suitable in order to produce the targeted knowledge of mathematics. The students realized the activities willingly and they expressed their thoughts clearly during the process of teaching.

\section{The Realization of Abstraction}

The subject of probability which was chosen as an objective has been conducted within the framework of activities. From this point of view, it can be said that abstraction is realized in the context of Leont'ev's (1981) activity theory. It has been seen that the students have conducted the structures of knowledge that was chosen as an objective. As a conclusion, the students participated in this study produced several forms of knowledge structures that are expected to be abstracted related to the subject of probability from simple to complex. Therefore, it can be said that there is a deepening in that structures of knowledge about the subject of probability (Dreyfus, et al., 2006). The concepts related to the subject of probability are not limited with the activities used in this study. The students needed to face with different problems and 
activities in order to reach more advanced and deeper abstraction levels.

\section{The Realization of Consolidation}

The formation of new structures of knowledge has been leading to the utilization and consolidation of the prior structures that were known before. For that reason, epistemological actions (recognize, build with, construction) of abstraction can not always be easily differentiated from the actions at the consolidation phase. For example, it has been seen that the scientific probability concept which has been constructed as a theoretical probability concept by the students in the first activity have also been used in second, third and fourth activities by them. The activities in the study are suitable in terms of realizing the dialectical nature of abstraction (Özmantar\&Monaghan, 2007) and also this study exhibits that similar studies can be conducted for other mathematical subjects.

\section{Giriş}

Hızlı bir şekilde değişen ve gelişen dünyamızda, zor, sıkıcı ve soyut olarak bilinen matematiği öğrenmek bir zorunluluk haline gelmiştir. Bunu dikkate alan Millî Eğitim Bakanlığı (MEB, 2006) yeni bir program geliştirmiştir. Bu programda yetişen öğrencilerin, problem çözebilen, sorunlara farklı açılardan yaklaşabilen ve bilgiyi yapılandırabilen öğrenciler olması beklenmektedir (Katranc1, 2010). Bilginin yapılandırılması ile ilgili olan ve matematik öğretimi üzerinde etkili olan yaklaşımlardan bir tanesi Yapılandırmacı Öğrenme Kuramıdır. Bu yaklaşıma göre bilgi, kesin gerçekler değil bireyin yaşantı ve etkinlik- 
leriyle oluşan süreçlerdir. Bilgi, hiçbir zaman kişiden bağımsız değildir, duruma göre değişmekte ve bireysel olarak anlamlandırılmaktadır (Yurdakul, 2004). Bilgi, birey tarafından oluşturulmaktadır. Öğrenme nesnel değil özneldir. Herkes kendine özgü bir şekilde öğrenmektedir. Öğrenme, bireyin kendi deneyimlerinden anlam oluşturma süreci olarak tanımlanabilir. Bireyin, bilgiyi kendisinin oluşturduğu ve deneyimlerinden anlam oluşturduğu düşüncesi, araştırmacıları bilginin oluşturulma sürecini ve bu süreçte etkili olan faktörleri incelemeye yöneltmiştir.

Matematiğin bir soyutlama bilimi olması, araştırmacıları, bilginin oluşturulmasını soyutlama ile aynı anlamda kullanmaya yöneltmiştir. Çünkü matematik bir soyutlama bilimidir ve matematik kavramları, soyutlama sonucu elde edilmektedir (Altun, 2008). Bu çalışma da, olasılık konusu içerisinde yer alan deneysel ve teorik olasılık, bağımlı ve bağımsız olaylar kavramlarının soyutlanması ile ilgilidir. Bu çalışmada, belirlenen kavramların oluşturulması ve pekiştirilmesi süreçleri, yapılandırmacı yaklaşım çerçevesinde hazırlanmış bir öğrenme ortamında incelenmektedir. Çalışmanın, (i) yapılan öğretimin, problem çözme/etkinlik yapma tabanlı olması ve öğrencilerin informal bilgilerini kullanmalarına yer verilmesini sağlaması ve (ii) gerçek hayattan seçilen etkinlikler/problemler üzerinden yürütülmesi gerekmektedir.

Çalışma için seçilen olasılık, matematiğin bir olayın olma sıklığı ile ilgilenen dalıdır. Olasılık kavramının öğretiminin temel amacı, bir olayın olma ihtimali ile ilgili güçlü tahmin yapabilmektir (Altun, 2008) ve bu konu hem öğretmen hem de öğrencilerin işlenişinde zorluk çek- 
tikleri konuların başında gelmektedir (Gürbüz, 2006). Olasılık, birçok meslekte ve günlük hayatta aldığımız pek çok kararda önemli bir role sahip olmasına rağmen, olasılık kavramlarının anlaşılması birçok öğrenci için kolay değildir (Memnun-Sezgin, 2008). Bu çalışmadaki öncelikli amaç, öğrencilerin anlamlı matematik yapabilecekleri bir ortam hazırlamak, bu ortamda tasarlanan öğretimi uygulamak ve diğer matematik konuları için de uygun olabilecek bir model çalışma yapmaktır.

Matematiğin bir soyutlama bilimi olması ve matematik bilginin soyutlamalar sonucunda oluşması, bu çalışmanın da soyutlama kavramına dayandığını göstermektedir. Çalışmanın dayandığı temel kavramlardan soyutlama; Sierpinska'ya (1994) göre, “bir kavramdan belli özelliklerin ayırt edilmesi” olarak tanımlanmaktadır. En sade şekliyle soyutlama, "somuttan soyuta geçiş süreci" olarak bilinmektedir.

Günümüze gelindiğinde ise, bilim insanları soyutlamayı değişik bakış açıları altında incelemişlerdir. Bunlardan ilki bilişsel soyutlama görüşü, diğeri sosyo-kültürel soyutlama görüşüdür (Katranc1, 2010).

Soyutlamayı bilişsel olarak ele alan isimlerden ilki Piaget'tir. Piaget soyutlamayı, deneyimsel soyutlama ve sözde-deneyimsel soyutlama olarak ikiye ayırmıştır. Deneyimsel soyutlama, kavramlar arasındaki yüzeysel benzerliklere dayanmaktadır. Daha yalın bir ifadeyle deneyimci soyutlamanın, günlük hayattaki kavramları oluşturmaya yönelik bir soyutlama tipi olduğu söylenebilir (Mitchelmore, 2002). Her iki soyutlama türü de, kavramların ortak özelliklerini dik- 
kate almaktadır. Bunun yanı sıra sözde-deneyimsel soyutlama, eylemler arasındaki ilişkileri de göz önünde bulundurmaktadır (Katrancı, 2010). Soyutlamayı bilişsel yaklaşımla ele alan araştırmacıların, üç önemli ortak ifade üzerinde durdukları söylenebilir (Özmantar, 2005). Bunlar;

- Çok sayıdaki belli örneklerin ortak noktalarının tanınmasıyla ulaşılan genelleme,

- Düşük somut seviyelerden soyut düşüncenin yüksek seviyelerine tırmanış1,

- Ortamı çevreleyen koşullardan bağımsız olarak gerçekleşen bir süreç.

Onlara göre, soyutlama somuttan soyuta geçişte bir köprüdür ve bu benzerlikler dizisi sayesinde olur (Hershkowitz, Schwarz ve Dreyfus, 2001).

Sosyo-kültürel bakış açısına sahip psikologlar ise, soyutlamayı değişik şekillerde tanımlamışlardır. Örneğin van Oers (2001); 'soyut'un, bir kavramın yeni, daha önce fark edilmemiş bir özelliği değil, düşünmemize katkı sağlayan bir özellik olduğunu ifade ederek soyutlamayı "belli bir bakış açısından hareketle, iliş̧kilerin oluşturulması süreci" olarak tanımlamıştır.

Soyutlama süreci, doğrudan gözlenebilen bir durum olmadığından (Dreyfus, 2007), soyutlama süreci hakkında bilgi verebilecek gözlenebilir eylemlerin tanımlanmasına ihtiyaç duyulmuştur. Hershkowitz ve ark. (2001) tarafından üretilen ve bu çalışmada TKO 
olarak yeniden isimlendirilen RBC modeli bu çalışmanın teorik yapısı olarak seçilmiştir. Model; Tanıma (Recognizing), Kullanma (Building-with) ve Oluşturma (Constructing) eylemlerinin ilk harflerinin kullanılması ile adlandırılmıştır. Bu eylemlerin her biri gözlenebilir nitelikte olduğundan, soyutlama sürecinin derinlemesine incelenmesi mümkün olabilecektir.

TKO modeli, kendisine temel olarak birtakım sosyo-kültürel ve epistemolojik ilkeler tayin etmiştir. Bunlar ise Davydov'un (1990) bilgi oluşturma felsefesine dayalı ve Leont'ev'in (1981) etkinlik teorisine dayanmaktadır (Katrancı, 2010). Bu çalışmada da tanıma, kullanma ve oluşturma eylemlerinin gözlenmesi, etkinlik teorisine dayanmaktadır. Hazırlanan etkinlikler yardımıyla bu eylemler incelenmiştir.

Tanıma; bilinen yapıyı ifade eder (Bikner-Ahsbahs, 2004). Daha önce oluşturulan bir yapının kullanılmasıdır (Schwarz, Dreyfus, Hadas ve Hershkowitz, 2004). Öğrencinin, daha önceki etkinliğe benzer bir matematik yapı ile karşılaştığında, yeni etkinliğin matematiksel yapısı ile ilgili içsel ilişki kurması durumudur. Tanıma en az iki durumla ortaya çıkmaktadır. Bu durumlar; analoji ve özelleştirmedir. İçinde bulunulan epistemik eyleme göre bu durumlardan hangisinin gerçekleşebileceği değişmektedir. Yeni bir durumla karşılaşıldığında, daha önceki durumun sonucuna başvurulup bu yeni durumun bir öncekine benzediğine (analoji) veya özdeş olduğuna (özelleştirme) karar verilebilir (Dreyfus, Hershkowitz ve Schwarz, 2001). 
Kullanma; süreçte bilinen bilgi parçalarını yeni içerikle birleştirir. Tanıma sürecini de içine alır (Bikner-Ahsbahs, 2004). Verilen bir hedefi gerçekleştirmek için eskiden oluşturulan matematiksel yapıların kullanılmasıdır (Schwarz ve ark., 2004). Kullanma, öğrenciye ipucu verilmesi gibi bir kaynağın öğrenciye hatırlatılması ile de gerçekleşebilir (Hershkowitz ve ark., 2001). Kullanma genellikle öğrencinin problem çözme, matematiksel bir durumu anlama ve bu durumu açıklama veya bir süreç üzerinde dikkatle düşünmeye odaklanıldığında gerçekleşir. Bu eylemi gerçekleştirebilmek için öğrenciler, stratejilerin, kuralların veya teoremlerin yardımına başvurabilir. Bu eylem, öğrencilere konu ile ilgili bir ipucu verilmesi ya da kaynağın öğrenciye hatırlatılması ile de gerçekleşebilir (Hershkowitz ve ark., 2001).

Oluşturma; yeniden düzenleme ve yeniden yapılandırma süreçleri olarak tanınan, yeni bilginin yapılanması olarak bilinen süreçtir. "Var olan matematiksel bilgi bileşenlerinin bir araya getirilmesi ile bu bilgiler arasında yeniden bir düzenlemeye gidilmesi neticesinde, yeni bir anlam oluşturulması sürecidir” (Bikner-Ahsbahs, 2004). Ohlsson ve Lehtinen'e (1997) göre; oluşturma süreci, soyutlamanın ana basamağı olarak dikeysel yeniden düzenlenmiş bilgiyi içerir ve teorik düşünmeyi gerektirir. Oluşturma eylemi, TKO soyutlama modelinin merkezini oluşturmaktadır. Bu eylem olmadan soyutlama gerçekleşememektedir. $\mathrm{Bu}$ eylem; kişinin bir problem durumundaki tanıdığ1 yapıları, problem çözümünde kullanarak yeni yapılara ulaşmasıdır. Ulaşılan bu yeni yapılar ise, karşılaşılacak olan benzer problem durumlarında tanıma eylemindeki bilinmeyen yapıları ifade edecektir (Katrancı, 2010). Bu 
bağlamda, modeldeki oluşturma eylemi; kullanma ve tanıma eylemlerini içermektedir. Diğer bir deyişle tanıma, diğer iki eylemin, kullanma ve oluşturma eyleminin içinde yer alırken oluşturma eylemi bu üç epistemik eylemi de içerir. Bu eylemler birbiri içerisine geçmiş şekildedirler.

Soyutlamanın oluşumunda ayrıca birleştirmenin/pekiştirmenin önemli bir yeri bulunmaktadır. Soyutlamayı birleştirici bakış açısıyla ele alan TKO $+\mathrm{P}$ modeli tanıma, kullanma ve oluşturma eylemlerine pekiştirme (consolidation) eyleminin ilave edilmesi ile meydana gelmiştir. Pekiştirme; yeni bir etkinlik için daha önce uygulanan etkinliğin yapılarından yararlanma ve bu yapıları birleştirerek yeni bir yapı oluşturmadır (Katrancı, 2010). Pekiştirme, çeşitli durumlarda öğrencilerin, soyutlamayı kullanırken güvenli ve etkili olmalarını sağlamaktadır (Dreyfus ve Tsamir, 2001). Bir soyutlamanın pekiştirilmesinin karakteristikleri ise; yakınlık, özgüven, güvenirlik, değişkenlik ve farkındalıktır. Pekiştirme, bir soyutlama durumunda öğrencilerin kullanımına hazır olan uzun vadeli bir süreçtir.

Bu bağlamda soyutlamanın oluşumu, hem yapılandırma hem de pekiştirme basamaklarını içermektedir. Soyutlamanın yapısında lineer bir süreçten ziyade, diyalektik bir süreç söz konusudur. Bu bağlamda soyutlamanın oluşumu Şekil 1'de gösterilmiştir. 


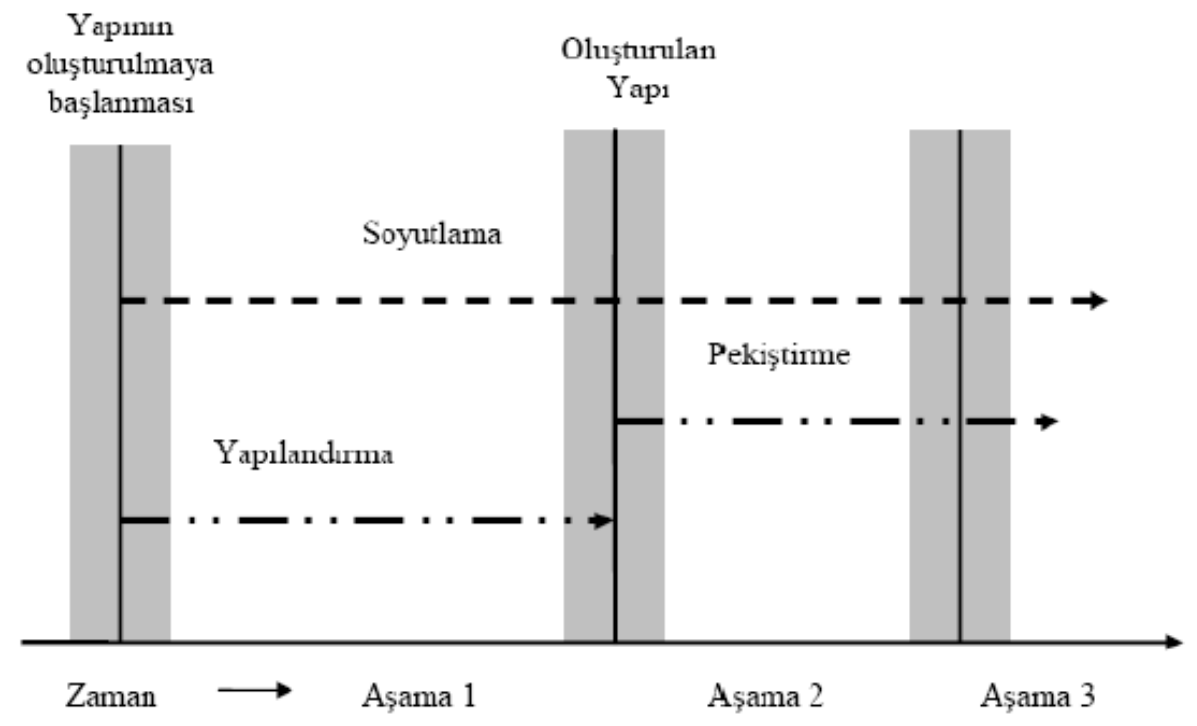

Şekil 1. Soyutlamanın oluşumu (Özmantar, 2005)

Soyutlama sürecinin analizi ile ilgili alan yazın tarihi oldukça yenidir ve yapılan çalışmaların bir kısmı sürecin tanınması ile ilgiliyken, diğer bir kısmı soyutlama süreci üzerindeki etkili olan faktörler ile ilgilidir. TKO modeline göre yapılan çalışmalar, TKO+P modeline göre yapılan çalışmalardan daha fazladır. Bu çalışmada ise $\mathrm{TKO}+\mathrm{P}$ modelindeki pekiştirme safhasına vurgu yapılmaktadır.

Hershkowitz ve ark. (2001) yaptıkları çalışmalarıyla, teorik ve deneysel soyutlamayı açıklamaya çalışmışlardır. Çalışmada, soyutlama sürecinin analizinde kullanılabilecek olan tanıma, kullanma ve oluşturma eylemlerini tanımlayarak TKO modelini ortaya çıkarmışlardır.

Yukarıda kısaca açıklanan çalışmanın devamı olarak Dreyfus, Hershkowitz ve Schwarz (2001) bir çalışma gerçekleştirmişlerdir. Bu 
çalışmada, akran etkileşimini ön plana çıkarmışlardır. Araştırmanın sonucunda, TKO modelinde tanımlanan epistemik eylemlerin, akran etkileşimiyle gerçekleştirilen soyutlama sürecini de analiz etmede kullanılabilecekleri tespit edilmiştir.

Hershkowitz (2004), öğrencilerin bilginin oluşturulması ve bilginin pekiştirilmesi süreçlerinin gözlemlenmesini temele alan bir çalışma yapmıştır. Çalışmada bilgi oluşturma ve bilginin pekiştirilme süreçleri, yine üç epistemik eylem (tanıma, kullanma ve oluşturma) üzerinden açıklanmıştır. Çalışma grubunu sekizinci sınıf öğrencileri oluşturmuştur. Olasılık konuları ile ilgili beş etkinlik, sekiz ders saatinde grup ve sınıf tartışması şeklinde uygulanmıştır. Etkinlikler, dört soru üzerinden yürütülmüş ve birincisi ile sınıf tartışması gerçekleştirilmiştir. Bu ilk soruya verilen cevaplar dikkate alınarak, iki öğrenci seçilmiş ve bu öğrencilerle ikinci soru ele alınarak akran etkileşimi ile bilgi oluşturma süreçleri incelenmiştir. Pekiştirme çalışması için ise üçüncü ve dördüncü sorular, ev ödevi olarak verilmiştir. Çalışma sonunda, olasılık ile ilgili bilgilerin yapılandırılabildiği fakat oluşturulan bilginin kalıcı olmadığı ortaya çıkmıştır. Bu nedenle, öğrencilerin olasılıkla ilgili yeni yapıları oluşturamadıkları sonucuna ulaşılmıştır.

Dreyfus, Hadas, Hershkowitz ve Schwarz (2006) yaptıkları çalışmada oluşturma ve pekiştirme süreçlerinin iç içe geçtiklerini ve pekiştirmenin yeni bir yapının oluşum sürecinde gerçekleştiğini iddia etmişler ve bu iddiaları ile ilgili bilgileri sunmuşlardır. Bu kapsamda çalışmada, beş sınıf gözlenmiş ve altı çift öğrenci ile görüşmeler yapılmıştır. Çalışmada olasılık konusu üç bölümde ele alınmıştır. Birinci 
bölüm; bir boyutlu uzayda olasılık hesaplama, ikinci bölüm; iki boyutlu örnek uzayda olasılık hesaplama ve basit olayların olasılığını hesaplama, üçüncü bölüm ise; eşit olasılığa ihtiyaç duyulmayan basit olayların, iki boyutlu örnek uzayda olasılığının hesaplanması ile ilgilidir. Veriler, üç kız öğrenciden oluşan grup şeklinde yapılan görüşmelerden elde edilmiştir. Sonuç olarak, öğrencilerin eski yapıyı kullanarak yeni yapının oluşturulmasında, o yapıyı pekiştirdiklerini tespit etmişlerdir. Pekiştirme eyleminin, yeni yapının üzerinde derinlemesine düşünülerek de gerçekleştirilebileceğini belirtmişlerdir.

Hershkowitz, Hadas, Dreyfus ve Schwarz (2007) paylaşılan bilgi oluşumu ve onun pekiştirilmesi sürecinin analizini yapmak için $\mathrm{TKO}+\mathrm{P}$ modelini kullanmışlardır. Çalışmanın amacı iş birliğiyle oluşturulan bilgi sürecini $\mathrm{TKO}+\mathrm{P}$ modeliyle tanımlanan epistemik eylemlerle açıklamaktır. Çalışmada olasılık konusu, bireysel, küçük grup tartışması ve sınıf tartışması şeklinde çalışılmıştır. Olasılık konusu ile ilgili üç hikâye, öğrencilerin bireysel olarak oluşturdukları bilgilerini kullanarak, paylaşım sonucunda yeni bilgiye ulaşabilmelerini sağlayacak şekilde düzenlenmiştir. Çalışma verileri, sekizinci sınıfta okuyan üç kız öğrencinin, grup çalışmasında gözlenmesiyle elde edilmiştir. Araştırmacı, grup çalışmalarının yapıldı̆̆g derslere katılarak gözlemler yapıp dersi videoya kaydetmiştir. Çalışmada TKO+P modelinin etkinliklerdeki soyutlama sürecinin analizinde kullanılabilecek bir araç olduğunu tespit etmişlerdir.

Bu çalışmada da, olasılık konusu ile ilgili deneysel ve teorik olasılık, bağımlı ve bağımsız olaylar kavramlarının soyutlanma ve 
pekiştirilme süreçleri incelenmiştir. Olasılık konusu ile ilgili daha özel kavramların soyutlanması ve TKO modeline sonradan eklenen Pekiştirme (P) eyleminin de açıklanmasından dolayı, çalışmanın literatüre katkı getireceği düşünülmektedir.

\section{Yöntem}

\section{Araştırmanın Modeli}

Bu çalışma, bir durum çalışması olan “örnek olay incelemesi”dir. Durum çalışmaları hem nitel hem de nicel olabilirken, her iki durumda da amaç belirli bir duruma ilişkin sonuçları ortaya koyabilmektir. $\mathrm{Bu}$ çalışmada ise; nitel bir durum çalışılmıştır. Nitel araştırma gözlem, görüşme ve doküman analizi gibi nitel veri toplama yöntemlerinin kullanıldığı, algıların ve olayların doğal ortamda, gerçekçi ve bütüncül bir biçimde ortaya konulmasına yönelik nitel bir sürecin izlediği araştırmadır (Yıldırım ve Şimşek, 2006).

Öğrencilerin bilgi oluşturma süreçlerini incelerken, TKO ve TKO+P modelleri referans alınmıştır. Görüşme, gözlem ve doküman analizi ile epistemik eylemler olarak bilinen tanıma, kullanma, oluşturma ve pekiştirme eylemleri incelenmiştir. Öğrencilerin günlük yaşantılarıyla ilgili dört etkinlik/problem kullanılmış ve bu etkinliklerin/problemlerin uygulanma sürecinde önceden edinilmiş bilgilerin tanınması, bu bilgilerin kullanılması, yeni yapıların oluşturulması sürecinde yaşanan düşünce biçimleri ve oluşturulan bilgilerin pekiştirilmesi incelenmiştir. 
Örnek olay incelemesinde ve nitel araştırmalarda, araştırmacı nicel çalışmalarda olduğu gibi sadece araştırma konusunu gözleyen değil, aynı zamanda konuyu ve katılımcıları daha iyi anlayıp analiz edebilmek için çalışmaya bizzat katılan, katılımcılarla birebir görüşen kişi konumundadır, yani sürecin bir parçasıdır (Yıldırım ve Şimşek, 2006). Bundan dolayı araştırmacı çalışmaya, katılımcı gözlemci konumunda dâhil olmuştur.

\section{Çalışma Grubu}

Çalışmaya katılan öğrencilerin seçiminde, öncelikle olasılık konusunu öğrenip öğrenemeyeceğini test etmek amacıyla, öğrencilerin ön bilgilerini yoklayıcı bir test uygulanmıştır. Ön bilgileri yoklamak amacıyla hazırlanan bu test, öncelikli olarak, seçilen okulun matematik öğretmenleri ile görüşülmüş ve uygun bulunmuştur.

$\mathrm{Bu}$ testin sonuçlarına göre çalışmanın evrenini oluşturan ve ilköğretim yedinci sınıfta okumakta olan 102 öğrenciden 65'inin olasılık konularını öğrenebilecekleri görülmüştür. Bu 65 öğrenciye ait SBS (Seviye Belirleme Sınavı) sonuçları ve matematik dersi not ortalamaları okul idaresinden alınmıştır. Elde edilen bu iki notun ortalamaları alınarak bir not çizelgesi oluşturulmuş ve matematik başarısı yükssek iki öğrenci bu çizelgeden seçilmiştir.

Seçilen bu iki öğrenciyle ve velileriyle birebir görüşülmüş, ça1ışmanın amacı ayrıntılı bir şekilde anlatılmış ve çalışma için gönüllü olup olmadıkları sorulmuştur. Çalışmaya katılma konusunda gönüllü oldukları yönünde sözlü beyanları alınmıştır. Çalışma içerisinde gerçek 
isimlerinin kullanılması ve çalışmanın videoya kaydedilmesi konularında bir itirazları olup olmadığı da ayrıca sorulmuş ve itirazları olmadığı, sözlü beyanları sonucunda belirlenmiştir. Bu bağlamda çalışmada kullanılan isimler öğrencilerin gerçek isimleridir. (BU: Burcu, B: Berkay, A: Araştırmacı).

\section{Veri Toplama Araçları ve Verilerin Toplanması}

Çalışmanın üzerinde yürütüldüğü etkinliklerin bulunduğu çalışma kâğıtları, video kayıtları ve çalışma ortamında yapılan gözlemler, çalışmanın veri toplama araçlarını oluşturmaktadır. Çalışma kâğıtları dört tane olup, her biri ilköğretim sekizinci sınıf olasılık konusu kavramları olan, deneysel ve teorik olasılık ile bağımlı ve bağımsız olaylar ile ilgilidir. Yapılan gözlemler ise yapılandırılmamış gözlemlerdir. Yapılandırılmamış gözlem, belirli bir zaman dilimindeki tüm davranışların kaydedilmesidir. Bu gözlemde araştırmacının özellikle ilgisini çeken ya da kaydetmeyi plânladığı davranışlar olmayabilir (Hovardaoğlu, 2000). Bu gözlem türünde, araştırmacı gözlediklerini düz yazıyla not etmektedir.

Etkinlik seçiminde ve türlerinin düzenlenmesinde klinik görüşmelerden beklenen sonuçları alabilmek için (i) tartışmaya elverişli, (i i)açık uçlu, (iii) öğrencilerin düşünme seviyelerini açıklığa kavuşturacak firsatlar sunması gibi özellikler (Tanış1, 2008) aranmıştır. Bu etkinliklerden "Etkinlik 1: Hangi Topu Seçmeli?" ve "Etkinlik 2: Kalemim Nerede?", TKO modeline göre, "Etkinlik 3: Kazan-Kaybet!" ve “Etkinlik 4: Çekme Şansı” ise TKO+P modeline göre öğrencilerin bilgi 
oluşturma süreçlerinin nasıl olduğunu göstermek amacıyla hazırlanmiştır.

Çalışma iki öğrenciyle aynı anda gerçekleştirilmiştir. Böylece öğrencilerin akran etkileşiminden yararlanması sağlanmaya çalışılmıştır. Çalışmada, doğru ya da yanlış cevaba ulaşmaktan çok, o cevaba ulaşma sürecinin incelenmesinin amaçlandığı açıklanmıştır. TKO modeline göre hazırlanan etkinlikler art arda aynı gün içerisinde çal1ş1ldıktan iki hafta sonra, TKO+P modeline göre hazırlanan etkinlikler çalışılmıştır. Yapılan her iki çalışma da, video kaydına alınmıştır. $\mathrm{Bu}$ kayıtlar analiz edilmiş ve rapor haline getirilmiştir.

\section{Verilerin Analizi}

Elde edilen verilerin analizinde ve yorumlanmasında nitel veri analiz türlerinden betimsel analiz kullanılmıștır. Betimsel analiz; elde edilen veriler, daha önceden belirlenen temalara göre özetlenir ve yorumlanır. Görüşülen ya da gözlenen bireylerin görüşlerini çarpıcı biçimde yansıtmak amacıyla doğrudan alıntılara sıkça yer verilir. Amaç, elde edilen bulguları düzenlenmiş ve yorumlanmış biçimde okuyucuya sunmaktır (Yıldırım ve Şimşek, 2006).

TKO ve TKO+P modelleri 1şığında yürütülen bu çalışmada öğrencilerin etkinlikleri, yaptıkları çalışma kâğıtları ve video kayıtları; tanıma, kullanma, oluşturma ve pekiştirme eylemlerine göre metinleştirilmiştir. Belirlenen bulgulara anlam kazandırmak, bulgular arasındaki ilişkileri açıklamak ve birtakım sonuçlar çıkarmak için de elde edilen verilere dayalı yorumlarda bulunulmuştur. 


\section{Çalışmanın Geçerlik ve Güvenirliği}

Çalışmada kullanılan etkinliklerin geçerlik ve güvenirlikleri, uzman görüşü alınarak sağlanmıştır. Nicel bir araştırmadan farklı olarak, nitel bir araştırma için Yıldırım ve Şimşek (2006), "iç geçerlik" yerine "inandırıcılık", "dış geçerlik" yerine "aktarılabilirlik”, “iç güvenirlik" yerine "tutarlık" ve "dış güvenirlik" yerine "teyit edilebilirlik" ifâdelerini kullanmayı tercih etmektedirler. Bu çalışmada da geçerlik ve güvenirlik, bu ifâdeler ışığında sağlanmıştır.

Guba ve Lincoln (1989) inandırıcılığı, katılımcının yapıyı alg1lama şekli ile araştırmanının kendi bakış açısını betimleme şekli arasındaki uyum şeklinde tanımlamaktadır. İnandırıcılığı artırmak için, araştırmacının birden çok stratejiyi kullanması önemlidir (Mertens, 1998). Bu bağlamda bu çalışmada; inandırıcılığı sağlamada, çeşitleme stratejileri kullanılmıştır. Gözlem ve görüşme yöntemleri kullanılarak yöntem çeşitlemesi yapılmış ve inandırıcılık sağlanmıştır. Örnek olay çalışmalarında geçerlik, “çoklu delil kaynaklarının” kullanımı ile sağlanabilir ve çeşitleme bunlardan biridir (Yin, 1994). Çeşitleme, insan davranışının bazı yönleri üzerine yapılan bir çalışmada iki veya daha çok veri toplama yönteminin kullanımı şeklinde tanımlanabilir (Cohen, Manion ve Morrison, 2002). Bu çalışmada, katılımcı gözlem ve görüşme yöntemleri kullanılarak yöntem çeşitlemesi yapılmıştır.

Yin (1994), örnek olay çalışmalarında, çoklu durum deseni kullanımının dış geçerliği artırdığını belirtmektedir. Yapılan bu çalışmada ise, öğrencilerin bilgi oluşturma ve matematiksel düşünme süreçleri, matematik başarısı yüksek olan öğrencilerle gerçekleştirilmiştir. Her 
iki öğrenci de yüksek seviyede başarılı olmalarına rağmen, bu seviyeler arasında da farklar bulunmaktadır. Bu şekilde oluşturulan çoklu durum deseni ile çalışmanın aktarılabilirliği (dış geçerliği) sağlanmıştır.

Nitel araştırmada tutarlık, ulaşılan sonuçların verilerle takip ve kontrol edilebilmesi ile sağlanmaktadır (Yin, 1994). Gerçekleştirilen çalışma süreci, metin içerisinde verilen, öğrencilerin bilgi oluşturma süreçlerine ait konuşma metinlerinin takibi ile çalışmanın tutarlığı sağlanmıştır.

Teyit edilebilirlik, delil zincirinin oluşturulması ile sağlanabilmektedir. Çalışma içerisinde, yeteri kadar konuşma metninin verilmesi önemli bir noktadır. Çalışmada gözlem ve görüşme notları ile teyit edilebilirlik sağlanmıştır.

\section{Bulgular ve Yorumlar}

Burcu ve Berkay ile birlikte yürütülen bu çalışmada, öğrencilerin olasılık konusu ile ilgili; deneysel ve teorik olasılık, bağımlı ve bağımsız olaylar kavramları, bilgi oluşturma süreçleri, tanıma, kullanma, oluşturma ve pekiştirme eylemleri ışı̆̆ında aşağıdaki şekilde ortaya konulmuştur. Öğrencilerin ve araştırmacının isimleri çalışma içerisinde aşağıda belirtildiği şekliyle kullanılmıştır: $B U$ : Burcu, B: Berkay ve A: Araştırmacı.

Burcu ve Berkay, çalışmanın TKO modeline göre hazırlanmış olan etkinliklerinin ilkiyle 24 dakika, ikincisi ile 19 dakika olmak üzere toplam 43 dakika zaman harcamışlardır. İki hafta sonra uygulanan ve araştırmanın $\mathrm{TKO}+\mathrm{P}$ modeline göre hazırlanmış etkinliklerinin ilkiyle 
20 dakika ve ikincisiyle 18 dakika olmak üzere toplam 38 dakika çalışmışlardır.

\section{Sürecin Analizi ve Yorumlar}

Etkinlik 1'in kâğıdı öğrencilere verildikten sonra, okumaları istenmiştir. Etkinliği inceleyen öğrencilere etkinlikte verilen niçin torbanın içinin görünmemesi gerektiği sorulmuştur. Bunun üzerine;

4B: Çünkü şimdi ĕger torbanın içi görünürse rasgele seçim olmaz yani belirli bir seçim olur. Çünkü içini görüyoruz, hangi topu seçeceğimizi görürüz.

... cevabı alınmıştır. Öğrencinin söylediği "rastgele seçim”, "belirli seçim" ifadelerinden bu kavramları tanıdi $\breve{g} l$ ve kullandi $\breve{g} l$ belirlenmiştir. Etkinliğe devam edilmiş ve istenilen uygulamaları gerçekleştirip aşağıdaki diyalogları yapmışlardır.

31A: Şimdi ne demek istiyor size? Bu tablo bize neyi açıklar?

32B: Olasılı̆̆ değil mi?

33A: Olasılık tamam ama 25 kere çekim yaptık?

34BU: Beyaz toplardan daha fazla vardı daha fazla beyaz çekim yaptık.

35B: Yeşil toplardan daha az vard,, neden aaa evet, öyle oldu!

Her iki öğrencinin de "olasılık” kavramını tanıdıkları ve kullandıkları görülmektedir. 35B'de öğrencinin şaşırmasının sebebi, torbada az sayıda bulunan rengin gelme olasılığının az olması gerektiğini düşünmesindendir. $\mathrm{Bu}$ durumda öğrencinin bu bilgi yapısını tanıdığ $l$ ve etkinlik içinde de kullandiğg görülmüştür. Bu bilgi daha önceki öğrenmelerinde oluşturulmuştur. Elde ettikleri verilere göre olasıllk değerlerini hesaplamaları istenmiş ve öğrenciler olasılık değerlerini yan- 
lışsız bir şekilde hesaplamışlardır. Bu durumda öğrencilerin, olasılık değerini hesaplama bilgisini daha önceden oluşturmuş oldukları görülmüştür. Olasılık değerlerini hesaplarken BU'nun, aşağıdaki ifadesi, onun "örnek uzay” kavramını tanıdığının ve kullandığının göstergesidir:

50BU: 25 kümenin bütün elemanları. 15, 5 tane. Burada da 13 kere çekmişiz.

Çalışmanın devamında,

58A: Bu olayı 25 kere değil de 50 kere yapabilir miydik?

59BU, B: Evet.

60A: 100 kere de yapabilirdik. Bu neyi değiştirir sizce?

61BU: Sayıları değiştirirdi.

62B: Oranları değiştirirdi.

şeklinde gerçekleşen diyalog, B'nin olasılık kavramının da bir oran olduğunu tanıdığının bir göstergesidir. Etkinliğin, teorik olasılık kavramının oluşturulmasına yönelik olan bölümüne geçilmiştir.

81BU: Torbadan bir top çektiğimizde bu topun yeşil top olma olasılı̆̆ kaçtır?

83B: 7 bölü 25.

84BU: 2 bölü 25. 1 dakika kaç yeşil var? 2 yeşil var. Toplam 10 var. 1 bölü 5 .

Öğrenciler, torbanın içindeki top sayılarına göre, gelme olasılıklarını hemen bulmuşlardır. Bu da, öğrencilerin aslında teorik olasılık konusunu tanıdıkları ve kullandıklarını göstermektedir. 84BU bu kavramları tanıdıklarının ve kullandıklarının bir kanıtı olarak gösterilebilir. Ayrıca 84BU’da öğrenci, olasılık değerini hesaplarken “2 bölü 10" ifadesi yerine direkt "1 bölü 5" demiştir. Bu da onun daha önceden 
oluşturmuş olduğu kesirlerde sadeleştirme işlemini çalışma içerisinde kullandı̆̆ının bir göstergesidir. Öğrencilerin, deneysel olasılık ve teorik olasılık kavramlarını oluşturmalarına yönelik diyaloglar aşağıdaki gibidir:

118A: Siz sadece fen bilgisi dersinizde mi deney yapıyorsunuz?

119B: Yoo matematikte de yapıyoruz.

120A: Bu biraz önce yaptı̆̆ını da matematiksel bir deneydir diyebilir misiniz?

121BU, B: Evet

122A: Bu çekme işlemlerine ne diyebiliriz?

123BU: Deney.

124A: Deney diyebiliriz. O zaman bu olasılı̆̆a nasıl bir olasılık diyebilirsiniz.

125B: Deney olastlığl.

131BU: 2.deki...(düşünür). Bilimsel olasılık olabilir.

Öğrencilerin, deneysel olasılık kavramını oluşturmuş oldukları görülürken, teorik olasılık kavramı için bilimsel olasılık kavramını ürettikleri görülmüştür. Tam olarak teorik olasılık kavramını üretemeyecekleri düşünülürse, bu olasılık kavramına karşılık bilimsel olasılık ifadesini kullanmış olmaları, onların bu bilgi yapısını oluşturduklarının bir göstergesi olarak kabul edilebilir.

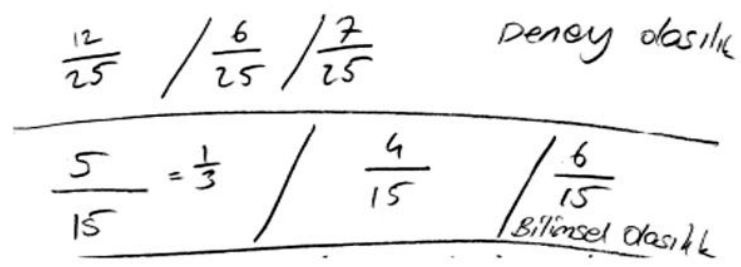

Şekil 2. Burcu'nun 1. Etkinlikteki Deneysel ve Teorik Olasılık Çalışmasına Ait Verileri 
Çalışmaya etkinliğin üçüncü bölümü ile devam edilmiştir.

172A: 9 tane top var. Nasıl açıklayabiliriz bunu?

173BU: Örnek uzayı azaltır.

174A: Tamam. Örnek uzay dediğiniz şey ne?

175BU: Bütün elemanlar.

Örnek uzay kavramı BU tarafından çalışmanın başında da kullanılmıştır. Burada da, çekilen topun geri konulmaması durumunda “örnek uzayı azaltır” ve "bütün elemanlar" ifadelerini kullanması bu kavramı daha önceden oluşturduğunun yani soyutladığının bir göstergesidir.

197BU: 1. çekiminiz 2. çekiminizi etkilemekte midir?

198B: Hayır etkilemez.

199BU: Yoo

200A: Neden etkilemez?

201B: Çünkü topu allyor çekiyor.

202BU: Önce 1. çekimi yaptık, 2. çekimle bir alakası yok.

203A: Neden yok?

204BU: Çünkü 1. çekimi daha önce yaptık, bir de topu geri attık 205A: Berkay?

206B: Zaten 1. de topu aldık, sonra geri attık, yine aynı sayıda top oldu.

Torbadaki top sayısının değişmediğini ifade etmeleri ve bu yüzden de olasılık değerlerinin değişmeyeceğini fark ettikleri, yukarıdaki konuşmalardan anlaşılmaktadır. Buradan öğrencilerin bağımsız olaylar kavramını tanımaya başladıkları söylenebilir.

Üçüncü bölümdeki olaylara B, “değişken olasılık” derken BU, "etken olasılık", "bağımlı olasılık” demiştir. 4. bölümdeki olaylara ise B, "sabit olasılık” derken, BU "bağımsız olasılık” demiştir. Bağımlı ve 
bağımsız olayları fark etmişler ve BU, bu kavramları kısmen de olsa oluşturmuştur. Çünkü olayları değil, olasılık değerlerini adlandırmıştır. Aşağıda BU'nun, çalışmanın bu bölümüne ait verileri gösterilmektedir.

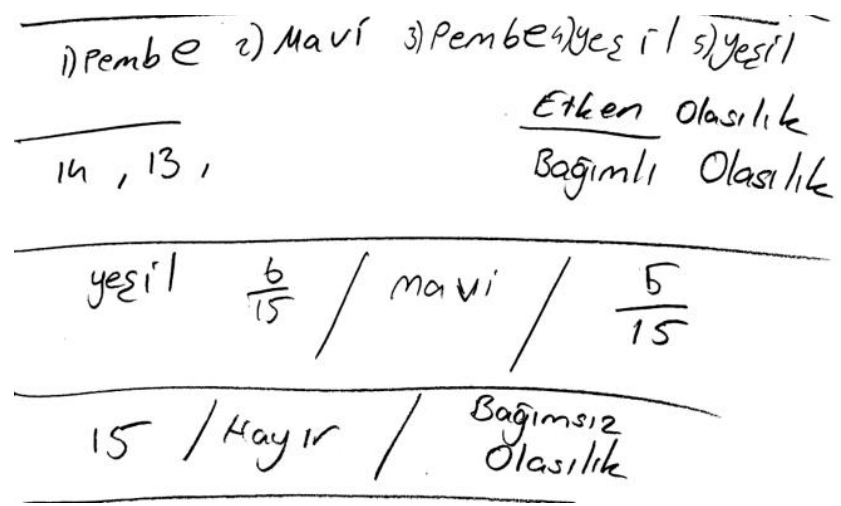

Şekil 3. Burcu'nun 1. Etkinlikteki Bağımlı ve Bağımsız Olaylar Çalışmasına Ait Verileri

Birinci etkinlik boyunca, öğrencilerin hem eğlendiği hem de hevesle çalışmayı sürdürdüğü görülmüştür. Ayrıca öğrencilerin, çekinmeden düşüncelerini dile getirebildikleri ve kamera çekiminden etkilenmedikleri de gözlemlenmiştir. Çalışmaya devam edilmiş ve ikinci etkinliğe geçilmiştir. Etkinlik yönergesinde istenilenler, öğrenciler tarafından uygulanmıştır.

322B: 5 bölü 15.

323BU: 1 bölü 3. Pembe kalem ve yeşil kalem. Pembe 4 tane var, yeşil de 6 tane.

324B: 4 bölü 15, 6 bölü 15.

325A: Güzel, peki çekimlerinize göre yaptı̆̆ınız olasılı̆̆a ne olasilı $\breve{g}$ demiştiniz?

326BU: Deney olasılığ .

328B: Ben olasılık demiştim.

330BU: Ben bilimsel olasılık demiştim.

331B: Ben olasılığı değiştirmek istemiyorum. 
323BU'da öğrencinin direk sadeleştirme yaparak sonucu söylediği görülmüştür. İlk etkinlikte de benzer şekilde ifade etmiştir. Bu da onun bu bilgi yapısını daha önceden oluşturmuş olduğunu, bu etkinlikte de kullandığını göstermektedir. Birinci etkinlikte, deneysel olasılığa karşılık kullandıkları “deney olasılığı”” kavramını bu etkinlikte de kullanmayı sürdürmüşlerdir. Böylece, bu bilgi yapısını oluşturdukları yani soyutlayabildikleri söylenebilmektedir. Etkinliğin, bağımlı ve bağımsız olaylar kavramlarına yönelik bölümüne geçmişlerdir.

373BU: Deney sayısını. 1. çekim ile 2. çekim arasında nasıl bir ilişki vardır? Az önce dediğim gibi.

376A: Neden etkileniyor?

377B: Çünkü kalemler azalıyor.

378A: Kalemlerin azalması bize neyi veriyor?

379B: Olasilık.

380BU: Çıkan renkten gelme olasiliğı azalıyor.

385A: Peki şimdi torbadan bir tane pembe çektik ve kenara koyduk, torbadan pembe çekilme olasılığı kaçtır?

386BU: 3 bölü 14.

387A: Demek ki ne oluyor?

388B: Azallyor. Ama diğerleri de arttı.

389A: Neden arttı peki?

390BU: Pembe sayısı azaldı diğerleri de arttı.

391A: Diğerlerinin artma sebebi ne?

392B: Çünkü kalem sayısı aynı kalıyor, mesela bu neydi yeşil miydi?

393A: Evet.

394B: Yeşiller 6 tane ya, 1 tane eksilince 14 kallyor. 6 bölü 14, 6 bölü 15 'ten daha büyük olduğu için.

Birinci etkinlikte olduğu gibi, bu olayların birbiriyle ilişkili olduğu bilgisini kullanmaktadırlar. 394B'de "6 bölü 14, 6 bölü 15'ten daha büyük olduğu için” ifadesi öğrencinin rasyonel sayılar arasında 
sıralama bilgisini daha önceden soyutlamış olduğunun bir göstergesidir ve bu bilgiyi burada da kullanmaktadır. Etkinliğin dördüncü bölümünde istenilenleri gerçekleştirmişler ve olayların bağımsız oldukları bilgisini oluşturmuşlardır. Bir önceki etkilikte oluşturmuş oldukları bu bilgi yapılarının devamını sağladıkları söylenebilir.

Öğrencilerin etkinlik sonunda eğlendikleri, düşüncelerini özgürce ifade ettikleri ve kamera çekiminden rahatsız olmadıkları gözlenmiştir. Çalışma bitiminden sonra öğretmenleri ile yapılan görüşmede, öğrencilerin benzer bir etkinliğin ne zaman yapılacağı konusunda heyecanlı olduklarını, bir an önce benzer bir etkinliğin yapılmaSını istediklerini belirttikleri belirlenmiştir.

Araştırmanın devamı olan ve bilgi oluşturma süreçlerinin pekiştirilmesine ağırlık veren bölümü 2 hafta sonra çalışılmıştır. Böylece öğrencilerin, bilgi yapılarını ne derecede pekiştirebilecekleri gözlenebilmiştir.

Üçüncü etkinliğe geçilmiştir. Etkinlik yönergesinde belirtilenler öğrenciler tarafından okunmuştur. Etkinlikte 40 kere çekim yapılması sonucunda kazananın belirlenebileceği belirtilmiştir. Bunun üzerine düşündükten sonra 13 kere de çekim yaparlarsa kazananı belirleyebileceklerini düşünmüşler ve 13 kere çekim işlemini gerçekleştirmişlerdir. Elde ettikleri verilere göre, olasılık değerlerini doğru bir şekilde hesaplamışlardır ve deney sayısının fazla olması durumunda, olasılık değerlerinin değişeceğinin farkındadırlar. Çalışma kâğıtlarına, her iki öğrenci de bu olasılık değerlerine karşılık deney olasılığ yazmıştır. $\mathrm{Bu}$ 
da onların, daha önceki etkinliklerde oluşturdukları bu kavramı pekiştirmiş olduklarını göstermektedir. 2. bölümdeki yönergelere göre, verilen sayıların olasılık değerlerini hemen hesaplamışlardır. Öğrenciler olasılık değerlerini hesaplama bilgisini pekiştirmektedirler. 2. bölümdeki olasılığa ise B, "tahmin olasılı̆̆ı", BU ise "verisel olasılık" demiştir. BU, daha önce bu olasılığa bilimsel olasılık demiştir. Bu açıdan bilimsel olasılık bilgisini pekiştiremediği söylenebilir. Fakat her iki adlandırma da öğrencinin bu bilgiyi soyutlayabildiğinin kanıtıdır. Pekiştirme etkinliğinin de, bu bilgiyi pekiştirdiği görülmektedir.

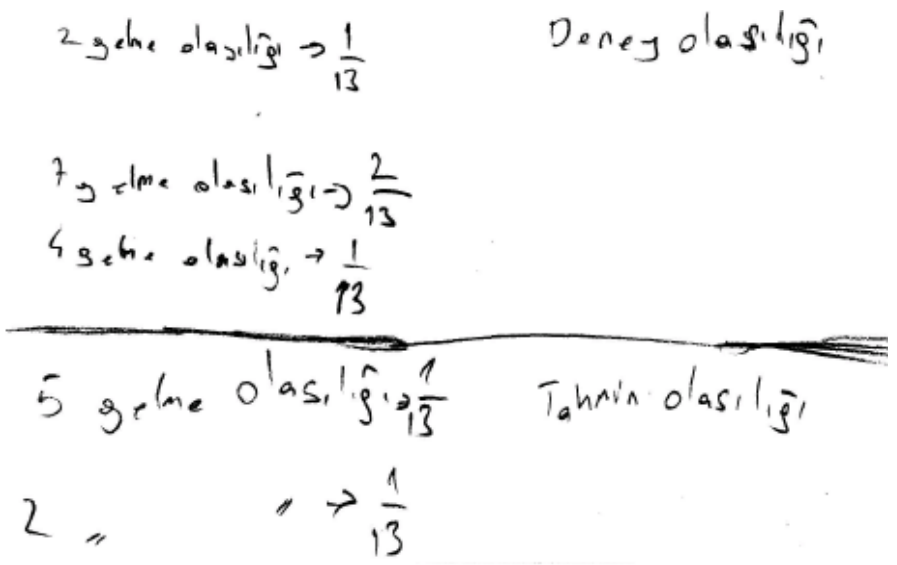

Şekil 4. Berkay’1n 3. Etkinlikteki Deneysel ve Teorik Olasılık Çalışmasına Ait Verileri

Etkinliğin, üçüncü ve dördüncü bölümlerindeki yönergeleri gerçekleştirmişlerdir. Öğrencilerin 1. ve 2. etkinlikte oluşturdukları bağımlı ve bağımsız olaylar kavramlarını, bu etkinlikte pekiştirdikleri görülmüştür.

617A: Peki bu olaylar birbirini etkiliyorsa, yani 1. olay 2. olayl etkiliyorsa, sizce bunlar nasil olaylardır? 
618BU: Bă̆ımll.

622BU: Çekilen taş geri konulmaz ise kendinden sonra çekilen tasların olasılığını etkiler.

642BU: Taşlar birbirini etkilemiyor.

643A: Bunu nasıl açıklarsınız? Etkilemediğini nasıl anladınız?

644BU: 2 gelme olasılı̆̆ hâlâ aynı.

645A: Birinci çekimle ikinci çekim arasında bir ilişki var mı? Bir etkilenme söz konusu mudur?

646BU: Hayır.

647A: Değil, o zaman bu olaylar nasıl olaylardır?

648B: Bă̆ımsız olaylar.

Öğrencilerin, bağımlı ve bağımsız olaylar kavramlarını pekiştirdikleri 618BU ve 648BU'da net bir şekilde görülmektedir.

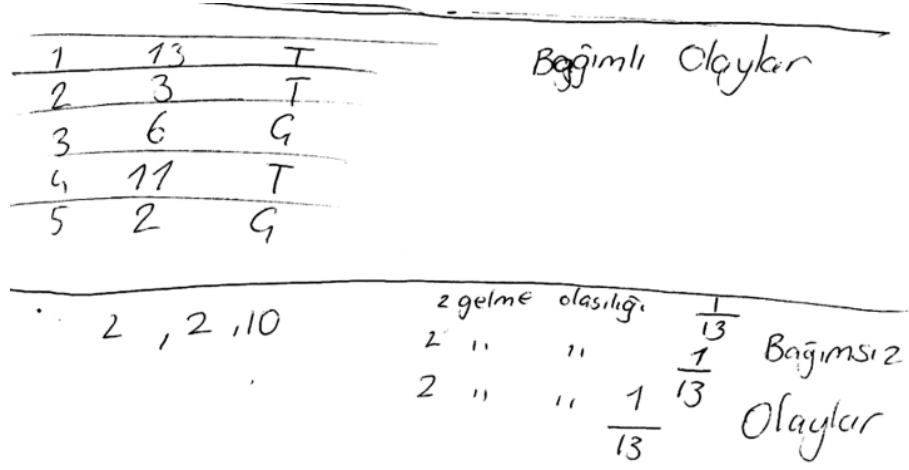

Şekil 5. Burcu'nun 3. Etkinlikteki Bağımlı ve Bağımsız Olaylar Çalışmasına Ait Verileri

Öğrencilerin, ilk çalışmadan iki hafta aradan sonra yapılan bu çalışmada da oldukça ilgili ve heyecanlı oldukları gözlemlenmiştir. Ayrıca öğrencilerin, etkinliği yaparken sıkılmadıkları, rahatça gerekli işlemleri gerçekleştirdikleri belirlenmiştir. 
BU'nun dördüncü etkinliği okumasıyla, çalışmaya başlanmıştır. Her ihtimale karşı, etkinliğin yapılacağı iskambil destesi öğrencilere tekrar tanıtılmıştır. Çekim sayısına göre, elde ettikleri verilerin olasılıklarını bulmuşlardır. Bütün olasılık değerlerini doğru bir şekilde hesaplamışlardır. Daha sonra çekim yapmadan da kartların çekilme olasılığını bulabileceklerini belirtmişler, buna göre de birkaç kartın çekilmesi olasılıklarını söylemişler ve not etmişlerdir. 1. bölüm ve 2 . bölümdeki olasılıkları adlandırmışlardır. Yine 1. bölümdekine deney olasılığı, 2. bölümdeki olasılığa da bilimsel olasılık demişlerdir.

703A: Peki yukarıdaki de bir olasılık aşağıdaki de bir olasılık, bu olasılıklar ne olasılıkları 1. işlemde yaptı̆̆ımız?

704B: 1. Deney olasilı̆̆l.

706BU: Bilimsel olasillk.

Öğrencilerin, deneysel olasılık ve teorik olasılık kavramlarını pekiştirdikleri görülmektedir. Her iki öğrenci de ilk iki etkinlikte bu kavramları oluşturmuş, sonraki iki etkinlikte de bu kavramları pekiştirmişlerdir. Bu da onların, bu bilgi yapılarını tamamen soyutladıklarının bir göstergesidir.

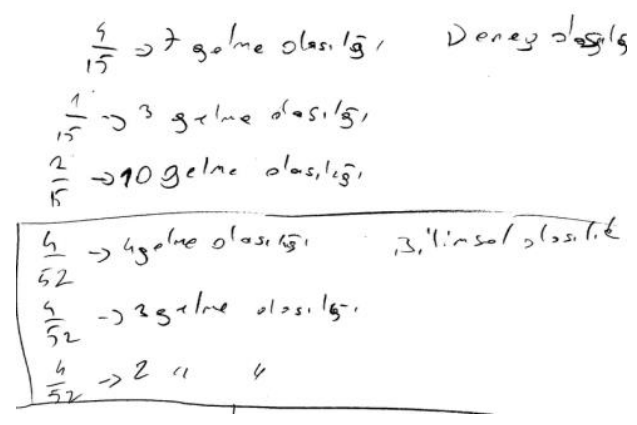

Şekil 6. Berkay'ın 4. Etkinlikteki Deneysel ve Teorik Olasılık Çalışmasına Ait Verileri 
Etkinliğin üçüncü ve dördüncü bölümlerindeki yönergelerde verilenleri gerçekleştirmişlerdir. İlk önce, desteden bir kart çekmişler ve geri koymadan olasılık değerlerinin değişip değişmediğini incelemişler, daha sonra yine bir kart çekip, desteye geri koymaları durumunda ne gibi değişikliklerin söz konusu olduğunu incelemişlerdir. Her iki bölüm içinde, olayların bağımlı ya da bağımsız olduklarını fark etmişler ve bu olayları bağımlı ve bağımsız olaylar olarak adlandırmışlardır. Öğrencilerin bu kavramları pekiştirdikleri görülmektedir.

770A: Bu ilişkiyi açıklayabilir misiniz?

771B: Bağımlı olasılık. Birbirine bağlı olaylar.

772A: Ne şekilde bă̆lllar?

773BU: Önceki olay sonrakini etkiliyor.

801A: Etkilemiyor. Bu tür olaylar nasıl olaylar o zaman?

802BU, B: Bă̆ımsız.

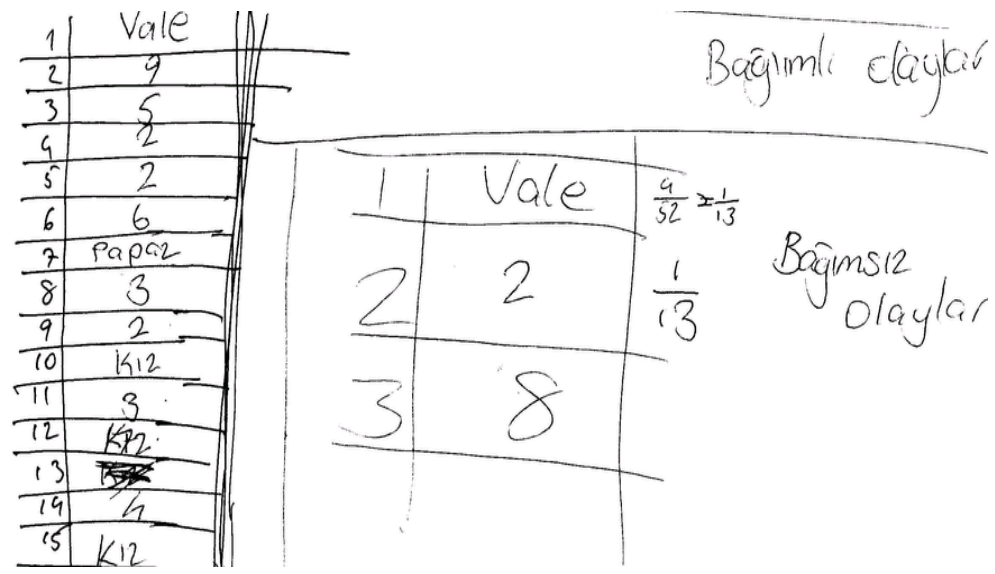

Şekil 7. Burcu'nun 4. Etkinlikteki Bağımlı ve Bağımsız Olaylar Çalışmasına Ait Verileri 


\section{Sonuç ve Tartışma}

Bu çalışmanın ana amacı, matematik başarısı yüksek ilköğretim öğrencilerinin olasılık konusu; deneysel ve teorik olasılık, bağımlı ve bağımsız olaylar kavramlarını oluşturma ve pekiştirme süreçlerini incelemektir. $\mathrm{Bu}$ amaçla çalışma, iki oturum şeklinde gerçekleştirilmiştir. Her bir oturumda, ikişer etkinlik üzerinde çalışılarak amaca ulaşılmak istenmiştir. Bu oturumlarda öğrencilerin konuşmaları, hâl ve hareketleri incelenmiştir. Çalışma süreci de dikkate alınarak çalışmanın sonuçları aşağıdaki üç başlık altında ele alınabilir.

\section{i. Öğrenme Ortamının, Bilginin Oluşturulma Sürecine Uygunluğu}

Çalışmada yapılan öğretimin tamamında, etkinlik yapma/çözme tabanlı öğretim yapılmış ve öğrenciler çalışmada yer alan bütün etkinliklere ilgi göstermişlerdir. Bu açıdan çalışmanın, soyutlamanın oluşması için çevre faktörünü dikkate alan Leont'ev'in (1981) etkinlik teorisine uyduğu söylenebilir. Hazırlanan etkinliklerin, hedeflenen matematiksel bilgiyi üretmek için uygun olduğu söylenebilir. Öğrenciler, etkinlikleri isteyerek gerçekleştirmişler ve öğretim süreci boyunca düşüncelerini açıkça belirtebilmişlerdir. Örneğin, birinci etkinlikte, torbadan hangi renkten top sayısı az ise, onun çekilme şansının az olacağını bildikleri görülmüş, fakat etkinlik esnasında bunun tam tersi bir olayla karşılaştıkları ve böyle bir durumla da karşılaşabileceklerini görmüşlerdir. Bu çalışmada öğrenme ortamı, hem öğrencilerin düşüncelerini özgürce ortaya koymalarına fırsat vermiş hem de yeni bilgi yapılarının oluşmasına imkân sağlamıştır. Etkinliklerin her birinin uygunluk düzeylerinin aynı olduğu söylenemez. Öğrencilerin, etkin- 
liklerin sunulduğu bağlamı tanıyor olmaları, gerekli ön bilgi yapılarını kullanma düzeyini etkilemekte ve yeni bilgiyi üretmekte önemli rol oynamaktadır. Bu çalışma için hazırlanan etkinlikler de, öğrencilere daha tanıdık gelebileceği düşünülen çerçevede hazırlanmaya çalışılmıştır. İlk iki etkinlikte kullanılan toplar ve kalemler, üçüncü etkinlikte kullanılan okey taşları, her iki öğrenci için de tanıdık olmasına rağmen, dördüncü etkinlikte kullanılan iskambil destesi, Burcu için daha tanıdık gelmiştir. Bu da Burcu'nun etkinliği daha rahat kavramasına imkân sağlamıştır.

\section{ii. Soyutlamanın Gerçekleşmesi}

Hedef olarak seçilen olasılık konusu, etkinlikler çerçevesinde çalışılmıştır. Bu açıdan soyutlamanın, Leont'ev'in (1981) etkinlik teorisi bağlamında gerçekleştiği söylenebilir. Öğrencilerin, hedeflenen bilgi yapılarını oluşturdukları görülmüştür. $\mathrm{Bu}$ durum etkinlikler üzerinde şu şekilde açıklanabilir:

Çalışmanın ilk bölümünde çalışılan etkinliklerin her birinin, ilk bölümleri; deneysel olasılık, ikinci bölümleri; teorik olasılık, üçüncü bölümleri; bağımlı olaylar ve dördüncü bölümleri; bağımsız olaylar kavramlarının oluşturulma süreçlerinin incelenmesi amacıyla hazırlanmıştır. Her bölümün ilk şıkları, öğrencilerin ön bilgi yapılarını yoklayacak ve hatırlatacak (bilgi yapılarını tanıyıp tanımadıklarını ortaya koyacak), ikinci şıkları ise; yeni bilgileri oluşturmalarına firsat verecek şekilde hazırlanmıştır. Belirlenen hedef kavramların soyutlanabilmesi için gerekli ön bilgi yapılarına, ne düzeyde sahip olduklarını ortaya çıkarmak için sorulan birinci şıklarda, öğrencilerin, ilk etkinlikte 
tartışma ihtiyacı duymalarına rağmen sonraki etkinliklerde bu safhayı doğrudan geçtikleri görülmüştür. Öğrencilerin, etkinliklerdeki konuşmalarından olasılık değerini hesaplama bilgisini, deneysel ve teorik olasılık kavramları ile bağımlı ve bağımsız olaylar kavramlarını, örnek uzay kavramını soyutladıkları görülmüştür. Bunların yanı sıra, olasıl1ğın da bir oran olduğu bilgisini ve kesirlerde sadeleştirme işlemini daha önceki öğrenmelerinde soyutladıkları söylenebilir.

Sonuç olarak çalışmaya katılan öğrenciler, bu çalışmada olasılık konusu ile ilgili soyutlanması beklenen bilgi yapılarının basitten karmaşığa doğru birçok formunu üretmiş̧lerdir. Dolayısıyla, olasılık konusu ile ilgili bilgi yapılarında bir derinleşme (Dreyfus ve ark., 2006) olduğu söylenebilir.

Olasılık konusu ile ilgili kavramlar, bu çalışmadaki etkinliklerle sınırlı değildir. Öğrencilerin daha ileri düzeyde ve daha derin soyutlama yapabilmeleri için farklı problemlerle, etkinliklerle karşılaşmaları gerekmektedir.

\section{iii. Pekiştirmenin Gerçeklemesi}

Yeni bilgi yapılarının oluşması, o safhada tanınan ön yapıların kullanılmasına, dolayısıyla pekişmesine yol açmaktadır. Bundan dolayı, çalışmada soyutlamanın epistemik eylemlerinin (tanıma, kullanma, oluşturma) pekiştirme safhasındaki eylemlerden ayrılması her zaman kolay olmamaktadır. Örneğin, öğrencilerin birinci etkinlikte bilimsel olasılık olarak oluşturdukları teorik olasılık kavramını, ikinci, üçüncü

ve dördüncü etkinliklerde de kullandıkları görülmüştür. Öğrencilerin 
birinci etkinlikte oluşturdukları bu kavramı, diğer etkinliklerde pekiştirmiş oldukları söylenebilir. Benzer şekilde deneysel olasılık kavramını da birinci etkinlikte oluşturmuşlardır. Teorik olasılık kavramı gibi, deneysel olasılık kavramını da ikinci etkinlikte pekiştirecekleri beklenirken, bu kavramı ikinci etkinlikte yeniden oluşturmak zorunda kalmışlardır. İlk etkinlikte tanınan deneysel olasılık kavramı, ikinci etkinlikte yeniden oluşturulmuştur. Bu kavramın üçüncü ve dördüncü etkinliklerde tamamen soyutlandığı ve pekiştirildiği söylenebilir.

Etkinlik 1: Kalemim Nerede? ve Etkinlik 2: Hangi Topu Seçmeli? etkinlikleri üzerinden çalışlarak oluşturulan olasılık konusu kavramları, benzer iki etkinlik üzerinde çalışılırken kullanılmış, üçüncü ve dördüncü etkinliklerdeki kullanma eylemi pekişmenin gerçekleşmesine yol açmıştır. Örneğin, öğrencilerin olasılık değerlerini akıldan söylemeleri, oranlı ifadelerde sadeleştirmeyi akıldan yapıp doğrudan söylemeleri bu bilgi yapılarının pekiştiğinin göstergesi olarak görülebilir.

Etkinlikler yardımıyla pekişmenin gerçekleşmesi ise aşağıdaki şekilde açıklanabilir. Etkinlik 1'de oluşturulan teorik olasıllk (öğrencilerin bilimsel olasılık olarak ifadesi kabul görmektedir), deneysel olasılık, bağımlı ve bağımsız olaylar kavramlarını, diğer etkinliklerde net bir şekilde pekiştirdikleri söylenebilir. İlk etkinliklerde öğrenciler tarafından sıkça kullanılan örnek uzay kavramının, öğrencilerin daha önceki öğrenmelerinde soyutlandığı ve bu çalışmada da pekiştiği görülmektedir. 
Sonuç olarak, çalışmaya katılan öğrencilerin hedeflenen bilgi yapılarının tamamını oluşturup soyutladıkları ve bazı kavramları ve işlemleri (örnek uzay, olasılık değerini hesaplama, sadeleştirme vb.) net bir şekilde pekiştirdikleri görülmüştür. Elbette, bu kavramları oluşturmanın ve pekiştirmenin, daha güçlü düzeyleri vardır ve bunların benzer etkinliklerle, yaşandıkça gerçekleşmesi beklenmektedir.

Hazırlanan etkinliklerin, yapılandırmacı kurama uygunluğunun ne derece önemli olduğu, etkinliklerin çalışılması sürecinde, öğrencilerin verdiği tepkilerden anlaşılmaktadır. Etkinlikler süresince öğrenciler, büyük bir gayret ve ilgi göstermişlerdir. Şevkle çalışmalarının yanı sıra, çalışmanın videoya kayıt edilmesinden rahatsız olmamış ve düşüncelerini rahat bir şekilde dile getirmişlerdir. İlk iki etkinliğin çalışmasının ardından bir sonraki çalışmanın ne zaman olacağı konusunda sabırsız oldukları, verilen iki haftalık arada sürekli öğretmenlerine "Ne zaman tekrar çalışma yapacağız?" diye sormalarından anlaş1lmıştır. Hem öğrenciler hem de öğretmenler için zor olarak bilinen olasılık konusunun çalışılmasını zevkli hale getiren şeyin, etkinliklerin yapılandırmacı kurama göre hazırlanmış olması olarak düşünülebilir. $\mathrm{Bu}$ da, bu kuramın önemini ortaya çıkarmaktadır. Çalışmadaki etkinliklerin, soyutlamanın diyalektik doğasının (Özmantar ve Monaghan, 2007) görülmesi bakımından uygun olduğu görülmektete ve çalışma, diğer matematik konuları için benzer çalışmaların yapılabileceğini ortaya koymaktadır. 


\section{Kaynakça}

Altun, M. (2008). İlköğretim ikinci kademe (6, 7 ve 8. sinıflarda) matematik öğretimi. Aktüel Yayınları: Bursa.

Bikner-Ahsbahs, A. (2004). Towards the emergence of constructing mathematical meanings. Proceedings of the 28th Conference of the International Group for the Pychology of Mathematics Education. 2, 119-126.

Cohen, L., Manion, L. ve Morrison, K. (2002). Research methods in education. Routledge Publications: London.

Davydov, V. V. (1990). Soviet studies in mathematics education: Vol. 2. Types of generalization in instruction: logical and psychological problems in the structuring of school curricula. (J. Teller, Çev.). Reston, Virginia: National Council of Teachers of Mathematics. (Orijinal çalışma basım tarihi 1972).

Dreyfus, T. ve Tsamir, P. (2001). Ben's consolidation of knowledge structures about infinite sets. Journal of Mathematical Behavior, 23, 271-300.

Dreyfus, T., Hershkowitz, R. ve Schwarz, B. (2001). Abstraction in context: The case of peer interaction. Cognitive Science Quartely, 1(3), 307-368.

Dreyfus, T., Hadas, N., Hershkowitz, R. ve Schwarz, B. B. (2006). Mechanisms for consolidating knowledge construct. J. Novotná, H. Moraová, M. Krátká, ve N. Stehlíková (Ed.), Proceedings of the 30th Conference of the International Group for the Psychology of Mathematics Education içinde (465-472). Prague, Czech Republic: Charles University Faculty of Education.

Dreyfus, T. (2007). Processes of abstraction in context the nested epistemic actions model. 22.09.2008, 
http://cresmet.asu.edu/news/i2/dreyfus.pdf.

Guba, E. G. ve Lincoln, Y. S. (1989). Fourth generation evaluation. Newbury Park, CA: Sage.

Gürbüz, R. (2006). Olasılık kavramlarıyla ilgili geliştirilen öğretim materyallerinin öğrencilerin kavramsal gelişimine etkisi. Dokuz Eylül Üniversitesi Buca Eğitim Fakültesi Dergisi, 20, 59-68.

Hershkowitz, R. (2004). From diversity to inclusion and back: lenses on learning. M. J. Hoines ve A. B. Fuglesad, (Ed.), Proceedings of the 28th Conference of the International Group for the Psychology of Mathematics Education, 1 içinde (55-68). Norveç: Bergen University College.

Hershkowitz, R., Schwarz, B. ve Dreyfus, T. (2001). Abstraction in contexts: epistemic actions. Journal for Research in Mathematics Education, 32(2), 195-222.

Hershkowitz, R., Hadas, N., Dreyfus, T. ve Schwarz, B. (2007). Abstracting processes, from individuals' constructing of knowledge to a group's shared knowledge. Mathematics Education Research, 19(2), 41-68.

Hovardaoğlu, S. (2000). Davranış bilimleri için araştırma teknikleri. Ankara: Ve Ga Basın Yayın Dağıtım.

Katrancı, Y. (2010). Olasılı̆̆ın temel kuralları bilgisinin yapılandırmacı kurama göre oluşturulması sürecinin incelenmesi. Yayınlanmamış yüksek lisans tezi, Uludağ Üniversitesi Sosyal Bilimler Enstitüsü.

Leont'ev, A. N. (1981). The problem of activity in psychology. J. V. Wertsch (Ed.), The concept of activity in Soviet psychology içinde (37-71). Armonk, NY: Sharpe. 
Memnun-Sezgin, D. (2008). Olasılık kavramlarının öğrenilmesinde karşılaşılan zorluklar, bu kavramların öğrenilememe nedenleri ve çözüm önerileri. İnönü Üniversitesi Ĕ̆itim Fakültesi Dergisi, 15, 89-101.

Mertens, D. (1998). Research method in education and psychology. London: Sage Publications.

Milli Eğitim Bakanlı̆̆ı. (2006). İlköğretim matematik dersi 6-8. sinıflar ögretim programı. Ankara: MEB.

Mitchelmore, M. C. (2002). The role of abstraction and generalisation in the development of mathematical knowledge. D. Edge ve Y. B. Har, (Ed.), Mathematics education for a knowledge-based era (Proceedings of the Second East Asia Regional Conference on Mathematics Education and the Ninth Southeast Asian Conference on Mathematics Education içinde (157-167). Singapur: Association of Mathematics Educators.

Ohlsson, S. ve Lehtinen, E. (1997). Abstraction and the acquisition of complex ideas. International Journal of Educational Research, 27, 37-48.

Özmantar, M. F. (2005). An Investigation of the formation of mathematical abstractions through scaffolding. Yayınlanmamış doktora tezi, University of Leeds.

Özmantar, M. F. ve Monaghan, J. (2007). A dialectical approach to the formation of mathematical abstractions. Mathematics Education Research Journal, 19 (2), 89-112.

Schwarz, B., Dreyfus, T., Hadas, N. ve Hershkowitz, R. (2004). Teacher guidance of knowledge construction. M. J. Hoines ve A.B. Fuglesad, (Ed.), Proceedings of the 28th Conference of the International Group for the Psychology of Mathematics Education 
4 içinde (169-176). Norveç: Bergen University College.

Sierpinska, A. (1994). Understanding in mathematics. London: Falmer.

Tanışl1, D. (2008). Illköğretim beşinci sınıf öğrencilerinin örüntülere ilişkin anlama ve kavrama biçimlerinin belirlenmesi. Yayınlanmamış doktora tezi, Anadolu Üniversitesi Eğitim Bilimleri Enstitüsü.

Van Oers, B. (2001). Contextualisation for abstraction. Cognitive Science Quartely, 1(3), 279-305.

Yıldırım, A. ve Şimşek, H. (2006). Sosyal bilimlerde nitel araştırma yöntemleri. Ankara: Seçkin Yayıncılık.

Yin, R. (1994). Case study research: Design and methods. California: Sage Publications.

Yurdakul, B. (2004). Yapılandırmacı öğrenme yaklaşımının öğrenenlerin problem çözme becerilerine, biliş ötesi farkındalık ve derse yönelik tutum düzeylerine etkisi ile ögrenme sürecine katklları. Yayınlanmamış doktora tezi, Hacettepe Üniversitesi, Sosyal Bilimler Enstitüsü. 